\title{
Effect of Variations and Types of Filler on Compressive Strength and Density of CLC Light Bricks
}

\author{
Dwi Pangga ${ }^{1}$, Dwi Sabda Budi Prasetya ${ }^{2 *}$, Habibi $^{3}$ \\ 1,2,3 Department of Physics Education, Universitas Pendidikan Mandalika \\ Pemuda Street 59 Mataram, Nusa Tenggara Barat, Indonesia \\ * Corresponding author: \\ Email: dwisabda@ikipmataram.ac.,id
}

\begin{abstract}
.
In the process of producing light brick, there is 'mixed foam' agent to reduce the value of its density, therefore it can reduce the values of compressive strength. To reduce its density and increase the value of pressure, the variations and types of fillers must match the composition. The manufacture of light brick type CLC (Cellular Lightweight Concrete) has been carried out with several variations and types of fillers to compare the values of compressive strength and density. The fillers are as follows: Water Hyacinth, Banana Midrib, and Wood Shavings based on gold processing waste $(G P W)$. The compressive strength and density test results on various filler percentages are as follows: 1). Water hyacinth at the percentage of $0 \%, 15 \%, 30 \%, 45 \%, 60 \%$ has compressive strength: $(2.43 ; 0.73 ; 0.69 ; 0.59 ; 0.65)$ $\mathrm{MPa}$ while the densities are $\left.(1.62 ; 1.20 ; 1.41 ; 1.13 ; 1.20) \mathrm{gr} / \mathrm{cm}^{3} .2\right)$. Banana midrib with variations are: $0-4$ midribs has compressive strength: $(2.43 ; 1.25 ; 1.68$; 2.13; 1.32) $\mathrm{MPa}$ and its densities are $(1.62 ; 1.29$; 1.12 ; $\left.1.16 ; 1.25) \mathrm{gr} / \mathrm{cm}^{3} .3\right)$. Wood shavings with percentage: $0 \%, 25 \%, 50 \%, 75 \%$ have compressive strength: $(2.43 ; 1.39 ; 2.04 ; 1.72) \mathrm{MPa}$ and their densities: $(1.62 ; 1,21 ; 1.26 ; 1.20) \mathrm{gr} / \mathrm{cm}^{3}$. The results showed that the best compressive strength was produced by the filler from wood shavings with an average of $1.85 \mathrm{MPa}$ and a density of $1.31 \mathrm{gr} / \mathrm{cm}^{3}$. The lowest density was obtained from the banana midrib filler which was $1.29 \mathrm{gr} / \mathrm{cm} 3$ with a compressive strength of $1.76 \mathrm{MPa}$. It can be concluded that light brick is best suited to wood shavings fillers.
\end{abstract}

Keywords: Light brick, Filler, Water hyacinth, Banana midribs, Wood shavings.

\section{INTRODUCTION}

Light brick type CLC is easier to develop than AAC. Producing light brick types of CLC can be done by various communities because the drying process is natural. The composition of the materials must be matched, therefore it must be investigated to produce a high compressive strength and the lowest density value. Pangga, 2018 [1-2] has found that there is a correlation between compressive strength and light brick density values. The tendency will be seen when the density is controlled at a low position, the compressive strength is decreased. Conversely, when the compressive strength is controlled at a high position, the density is increased. This condition must 
be avoided in the process of making light bricks. It is expected, by increasing the value of compressive strength, the density values are between $0.6-1.8 \mathrm{gr} / \mathrm{cm} 3$ to be classified as light brick [3-6]. To obtain optimal results (high compressive strength and low density), the use of fillers and variations in the composition of the fraction is an alternative solution.

Various types of fillers can be applied to obtain lightweight bricks which have different compressive strength and density values. Some fillers that have been used to produce light bricks with high compressive strength and low density are as follows: water hyacinth, banana midrib, pumice, wood shavings, and rice husk ash [3]. The fillers have different characteristics and properties, therefore each needs to be optimized for the percentage of the materials, as well as the function of the fillers to produce light bricks with the expected properties.

Generally, conventional bricks have compressive strength and density which are 9.29 MPa [8] and $0.65 \mathrm{gr} / \mathrm{cm} 3$. Meanwhile the light brick in trade has a compressive strength and density of 2.5-25 MPa and $1.8 \mathrm{gr} / \mathrm{cm} 3$. Haryanti [9-11] found that, light brick with a ratio of cement and ash composition of : $50 \%$, and foam mixture (polymer and hardener) respectively: $50 \%$ produced the average compressive strength and the highest density was $3.99 \mathrm{MPa}$ and $0.78 \mathrm{gr} / \mathrm{cm} 3$.

The results of these studies as a basis for making light brick by utilizing materials around which have not been utilized to the fullest. Consequently, the use of these materials is certainly still not in accordance with the general standard, therefore it is necessary to modify the composition in the manufacturing process. This study uses gold processing waste as its basic ingredients, and several types of fillers as reinforcement. The filler variations are as follows: water hyacinth, banana midrib, and wood shavings. The three ingredients are very easy to find and have not been utilized maximally.

\section{METHODS}

Preparation of materials are carried out as follows:

1. Gold processing waste (GPW) obtained from traditional GPW of Sekotong community, west Nusa Tenggara, Indonesia.

2. Water hyacinth stems that have been dried before they are brittle, then make the appropriate pieces.

3. Banana midribs can be a midrib or stem stem. All dried and cut into small pieces as needed..

4. Wood shavings are obtained in a rather rough size

5. Other supporting materials such as foam agents (foam) and cement.

All GPW materials are mixed and vary the types of fillers to be used according to the procedure as follows: 


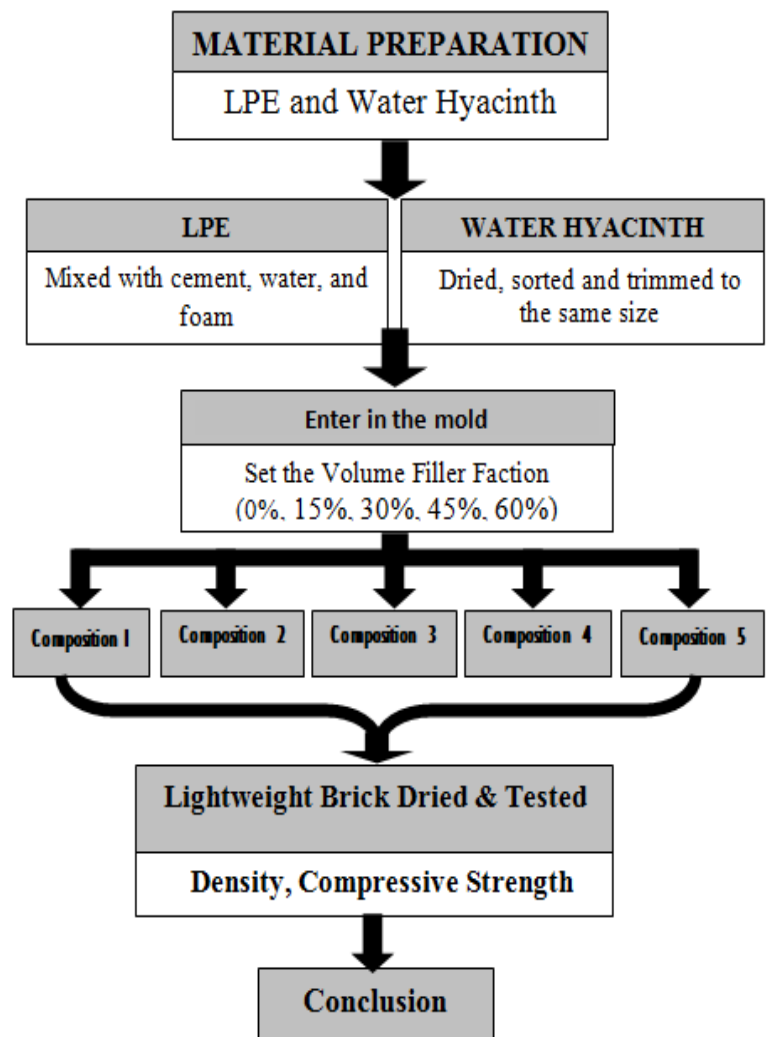

Figure 1. Research Flow

Each filler from banana midribs and wood shavings (Figure 1) can be compared. Lightweight bricks that have been finished can be dried naturally to be tested for density and compressive strength, (UTM Alfantes 9) [13].

\section{RESULT AND DISCUSSION}

The results showed that the optimization of the composition between water, cement, and GPW as basic materials greatly affected the light brick product. The next process, mixing the filler into the mixture with the percentages as follows:

a. Water hyacinth fillers are randomized with a percentage of volume fraction: $0 \%$, $15 \%, 30 \%, 45 \%$, and $60 \%$.

b. Filler of banana midrib with variation of 0-4 midribs.

c. Wood shavings filler with a percentage of volume fraction of $0 \%, 25 \%, 50 \%$, and $75 \%$.

The manufacturing process is shown in Figure 2, while the results of compressive strength and density analysis are shown in tables 1,2 , and 3. 


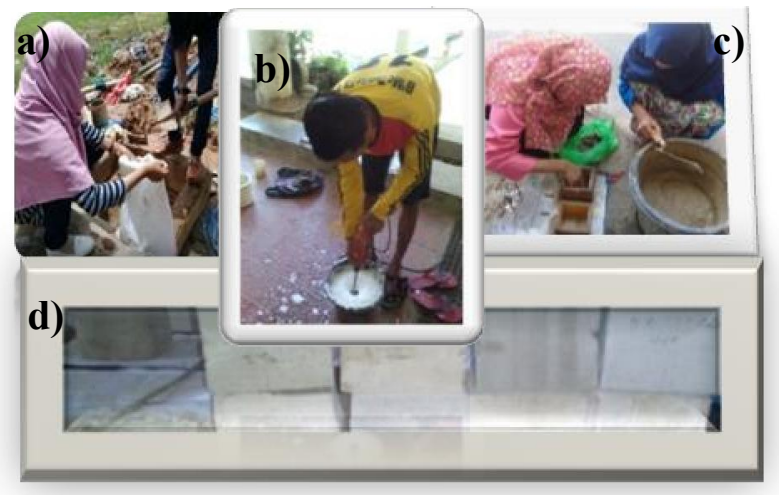

Figure 2. The process of making light bricks: a) Preparation of materials; b) Manufacture of foam; c) Pouring the poured filler according to the type of filler and its percentages; d) Light brick products.

Table 1. Comparison of Compressive Strength and Density of Hyacinth Filler

\begin{tabular}{cccc}
\hline No & $\begin{array}{c}\text { Composition of water } \\
\text { hyacinth filler } \\
\text { volume fraction (\%) }\end{array}$ & $\begin{array}{c}\text { Compressive } \\
\text { strength } \\
(\mathrm{MPa})\end{array}$ & $\begin{array}{c}\text { Density } \\
\left(\mathrm{gr} / \mathrm{cm}^{3}\right)\end{array}$ \\
\hline 1 & 0 & 2.43 & 1.62 \\
2 & 15 & 0.73 & 1.20 \\
3 & 30 & 0.69 & 1.41 \\
4 & 45 & 0.59 & 1.13 \\
5 & 60 & 0.65 & 1.20 \\
\hline & Average & 1.02 & 1.31 \\
\hline
\end{tabular}

Lightweigh brick without water hyacinth (0) has a higher compressive strength than water hyacinth filler. This condition occurs in all percentages when the percentage of water hyacinth filler increases, causing the compressive strength to decrease (Table 1). This phenomenon occurs because the adhesive forces between basic materials and fillers are lower than cohesive. Therefore the dynamic load will release the bond between the matrix and filler earlier than the bond between the matrix and between the fillers. Finally, this condition will cause the material to crack because of the small compressive force.

However, it was seen that the addition of water hyacinth filler caused a decrease in the density value from the previous $1.62 \mathrm{gr} / \mathrm{cm} 3$ to be lower. This condition has been influenced by the low density of water hyacinth.

Table 2. Compressive Strength and LightweighBrick Density using Banana Midribs/LayersFiller

\begin{tabular}{cccc}
\hline No & $\begin{array}{c}\text { Composition of the } \\
\text { number of banana } \\
\text { midrib layers }\end{array}$ & $\begin{array}{c}\text { Compressive } \\
\text { strength } \\
(\mathrm{MPa})\end{array}$ & $\begin{array}{c}\text { Density } \\
\left(\mathrm{gr} / \mathrm{cm}^{3}\right)\end{array}$ \\
\hline 1 & Without layers & 2.43 & 1.62 \\
2 & 1 Layer & 1.25 & 1.29
\end{tabular}


International Journal Of Science, Technology \& Management

\begin{tabular}{lrll}
3 & 2 Layer & 1.68 & 1.12 \\
4 & 3 Layer & 2.13 & 1.16 \\
5 & 4 Layer & 1.32 & 1.25 \\
\hline & Average & 1.76 & 1.29 \\
\hline
\end{tabular}

A similar condition also occurs in light brick with fillers from banana midribs, a number of filler layers cause low compressive strength. Likewise, the density tends to be lower (Table 2). There is a similar tendency (Table 1), which means that physically hyacinth and banana midrib have similar characteristics.

Table3. Compressive Strength and Lightweight Brick Density Using Filler from Wood shavings

\begin{tabular}{cccc}
\hline No & $\begin{array}{c}\text { Composition Wood } \\
\text { Shavings filler (\%) }\end{array}$ & $\begin{array}{c}\text { Compressive } \\
\text { strength } \\
(\mathrm{MPa})\end{array}$ & $\begin{array}{c}\text { Density } \\
\left(\mathrm{gr} / \mathrm{cm}^{3}\right)\end{array}$ \\
\hline 1 & 0 & 2.43 & 1.62 \\
2 & 25 & 1.39 & 1.21 \\
3 & 50 & 2.04 & 1.26 \\
4 & 75 & 1.72 & 1.20 \\
\hline & Average & 1.85 & 1.32 \\
\hline
\end{tabular}

Light brick with wood shavings filler shows that the density value is quite high compared to the fillers of water hyacinth and banana midrib. There are optimum conditions for producing high compressive strength and lower density than without wood shavings fillers (Table 3). This condition occurs when the composition of $50 \%$ wood shavings filler produces compressive strength and density of $2.04 \mathrm{MPa}$ and 1.26 $\mathrm{gr} / \mathrm{cm} 3$. The use of wood shavings filler is more stable than water hyacinth and banana midrib. This condition is caused by the spread of filler in the base material more evenly and its small size. As a result, the filler surface is wider so that the adhesive force between the matrix and filler is greater than the cohesive force. Therefore, the dynamic load given to light bricks will be more evenly distributed.

Based on data in tables 1,2, and 3, it was found that the average compressive strength and density in each filler were as follows: water hyacinth was $1.02 \mathrm{MPa}$ and $1.31 \mathrm{gram} / \mathrm{cm} 3$; while for banana midribs $1.76 \mathrm{MPa}$ and $1.29 \mathrm{grams} / \mathrm{cm} 3$; and finally for wood shavings $1.85 \mathrm{MPa}$ and 1.31 grams / $\mathrm{cm} 3$. The three fillers, the density values are in the range of light brick categories [9] and [14-15]. The decrease in the density value is shown in Figures 3 and 4.

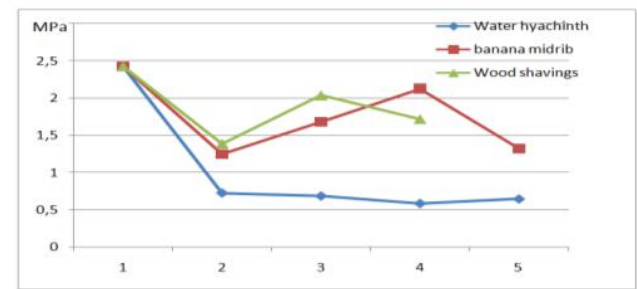

Figure 3. Comparison of Compressive Strength of the Materials Used http://ijstm.inarah.co.id 


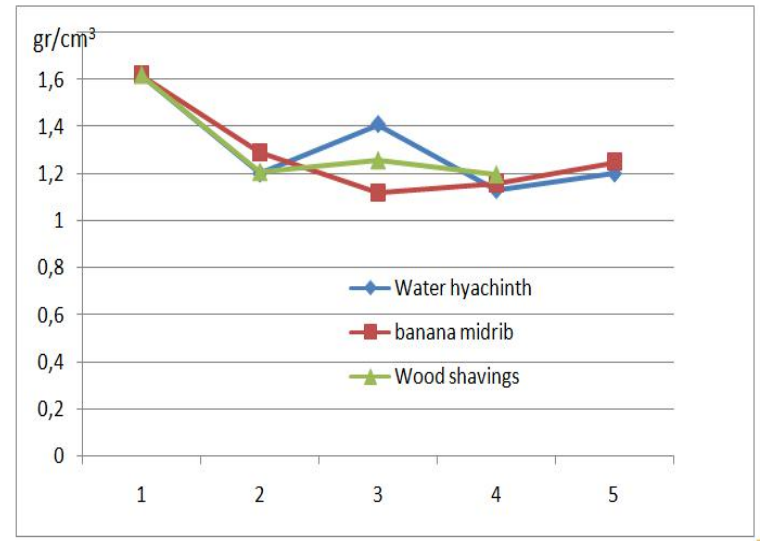

Figure 4. Comparison of Density Values

In Figures 3 and 4 combined with Tables 1, 2, and 3, it shows that the most stable compressive strength is light brick with wood shavings filler. However the density values of the three filler types are relatively stable and are included in the density range called light brick.

\section{CONCLUSION}

The types and variations in the percentage of filler are very influential on the value of compressive strength and light brick density produced. Light brick produced from the three types of fillers is a lightweight brick category with a range of 0.6-1.8 $\mathrm{gr} / \mathrm{cm}^{3}$. Types of fillers that are more profitable to develop are fillers from wood shavings. The value of compressive strength of wood shavings is more stable than fillers from banana midribs and wood shavings.

\section{REFERENCES}

[1] Pangga, Dwi dan Sabda Dwi. 2018. “Analisis Pengaruh Arah Serat Eceng Gondok terhadap Kuat Tekan dan Densitas Bata Ringan”. Universitas Islam Madura: Prosiding, Semnas Nacomse, 22 September 2018.

[2] K. Heathcote, Compressive strength of cement stabilized pressed earth blocks, Build. Res. Inf. 19 (1991) 101-105, https://doi.org/10.1080/0961321910872710

[3] Syarif H., Sabda Dwi, Pangga Dwi. 2017. "Pembuatan Batako Ringan dari Limbah Pengolahan Emas dengan Filler Eceng Gondok". Prosiding Seminar Nasional Ikatan Keluarga Alumni (IKA) IKIP Mataram Tahun 2017.

[4] F. Andreola, L. Barbieri, I. Lancellotti, C. Leonelli, and T. Manfredini, Recycling of industrial wastes in ceramic manufacturing: State of art and glass case studies, vol. 42, no. 12, pp. 13333-13338, September 20162016.

[5] J. Pickin, P. Randell Australian National Waste Report 2016, ed: Department of the Environment and Energy \& Blue Environment Pty Ltd 2017.

[6] Siram, Bhavani KK. dkk. 2012."Cellular Light-Weight Concrete Blocks as a Replacement of Burnt Clay Bricks". International Journal of Engineering and Advanced Technology (IJEAT)ISSN: 2249 - 8958, Volume-2, Issue-2, December 2012. 
[7] E. Adam, A. Agib, Compressed Stabilised Earth Block Manufacture in Sudan, Printed by Graphoprint United Nations Educ. Sci. Cult. Organ, France, Pa, 2001, p. 101. Available from : http://unesdoc.unesco.org/images/0012/ 001282/128236e.pdf

[8] Kumar Ravi, dkk. 2014. "Study Of Properties Of Light Weight Fly Ash Brick". International Journal of Engineering Research and Applications (IJERA) ISSN: 2248-9622. AET- 29th March 2014.

[9] Haryanti, NS. 2015. "Kuat Tekan Bata Ringan dengan Bahan Campuran Abu Terbang PLTU Asam-Asam kalimantan selatan”. Jurnal Fisika FLUX Vol. 12. No.1, Februari 2015.

[10] Tayfun Çiçek $\Uparrow$, Yasin Çinçin, 2015, Use of fly ash in production of light-weight building bricks, Construction and Building Materials 94 (2015) 521-527

[11] Bagheri, A. Nazari, J.G. Sanjayan, P. Rajeev, W.H. Duan, Fly ash-based boroaluminosilicate geopolymers: experimental and molecular simulations, Ceram. Int. 43 (5) (2017) 4119-4126.

[12] T. Adhavanathan, R. Neelaveni, 2019, Experimental Study On Fibre And Fly Ash Based Interlocking Bricks, Proceedings of 9th International Symposium (Full Paper), South Eastern University of Sri Lanka, Oluvil. 27th - 28th November 2019, ISBN: 978-955-627$189-8$

[13] Abolagba I. danOsuji S. dkk. 2017. "Assessment of Manufactured Sand in Concrete Produced with Palm Kernel Shells as Coarse Aggregate". International Journal of Science and Research (IJSR)ISSN (Online): 2319-7064.

[14] Balamurugan, M. Dkk. 2017. "Xperimental Study On Light Weight Foam Concrete Bricks". International Research Journal of Engineering and Technology (IRJET). Volume: 04 Issue: 04 | Apr -2017.

[15] U.S. Akhtar, M.M. Zaman, M.S. Islam, F. Nigar, M.K. Hossain, Effect of different types of glasses as fluxing agent on the sintering temperature of bricks, Trans. Indian Ceram. Soc. 76 (2) (2017) 128-132. 